\title{
"IT CHANGES YOUR LIFE": \\ THE VALUE OF FIELD TRIPS IN AFRICAN AMERICAN HISTORY FOR HIGH SCHOOL STUDENTS IN AN OUT-OF-SCHOOL-TIME PROGRAM
}

\author{
Russ Olwell, Mary-Elizabeth Murphy, and Pierre Rice \\ Eastern Michigan University
}

\begin{abstract}
This trip was very important to me. It's the first trip to an African American Museum and first culture trip I have been on, and it changed how I saw them. I admired what I saw and heard; all the difficulties they went through. It's inspiring how they stood up and fought for what was right.

-Student, African American History Program, Ypsilanti High School, Ypislanti, MI
\end{abstract}

During the school day in America, the field trip is an endangered species. With pressure for higher standardized test scores increasing and state funding decreasing, many schools have eliminated off-campus learning opportunities. This situation is particularly acute at the high-school level, where scheduling hurdles make it more difficult to take students out for a morning or a day, even for a worthy event or trip.

While research shows that properly structured field trips can be valuable for students - and particularly valuable for low-income or minority students who might not visit cultural institutions with their families - many administrators do not see their value. ${ }^{1}$ Many principals and district leaders value time "on task" in the classroom as the ideal use of student time. They consider trips a frill, given the financial cost and the loss of instructional time, even though research suggests that field trips have value for students, especially those with a personal or cultural connection to the out-of-school experiences.

In 2014, the Eastern Michigan University Bright Futures program received a grant from the Ann Arbor Area Community Foundation African American Fund to take students in a high school with a majority of low-income and minority students on a series of trips on the theme of African American history and culture. While students in Michigan are taught about many topics in African American history through the school curriculum, the field trip experience gave students an extra level of understanding that could not be accessed through classroom instruction alone.

\footnotetext{
${ }^{1}$ Jaye P. Greene, Brian Kisida, and Daniel H. Bowen, "The Educational Value of Field Trips," Education Next 14 (Winter 2014). Accessed October 16, 2015. http://educationnext.org/the-educational-value-offield-trips/; Marc Behrendt and Teresa Franklin, "A Review of Research on School Field Trips and Their Value in Education," International Journal of Environmental and Science Education 9, 3 (2014), $235-245$.
} 
This program brought students in Bright Futures in Ypsilanti Community Schools to a series of events centered on African American history and culture. Bright Futures is an after-school program, based on the idea of youth voice, which offers students opportunities for academic help. The aim of the project was to give students an opportunity to both increase their knowledge of and their appreciation for African American history and culture.

To develop this interest, the Bright Futures after-school program took students on a series of trips. Due to attendance fluctuations found in after-school programs, not all students attended every trip. Students traveled to the Charles H. Wright Museum of African American History in Detroit, visited a local African American bookstore, and attended an African American festival in Ann Arbor. Ninety-six unique students participated in these events.

Each field experience included an evaluation to measure what students found most important in their learning about the subject. These evaluations were transcribed, then coded by key themes by Russell Olwell and Mary-Elizabeth Murphy from the history faculty at Eastern Michigan University. After attending the trips and talking to students, Pierre Rice shared his interpretation of the data as well. After coding the data according to key themes, we identified three major categories of learning: learning about Africa, learning about the journey of Africans to America, and learning about the opportunities available to African Americans after the end of slavery.

\section{Learning about Africa}

Students reported learning a good deal about Africa through the program. They were particularly struck by the origin of humankind and human culture in Africa (including Lucy), and by the diversity of geography, cultures, and religions found in Africa. Students also reported learning about the types of culture in Africa, particularly musical or oral culture.

\begin{tabular}{|l|c|}
\hline $\begin{array}{l}\text { Students learned about the central role of Africa in } \\
\text { history and the development of human culture }\end{array}$ & 17 \\
\hline $\begin{array}{l}\text { Students learned about the diversity of Africa and } \\
\text { African life }\end{array}$ & 6 \\
\hline $\begin{array}{l}\text { Students learned about the rich oral culture of Africa } \\
\text { in songs and language }\end{array}$ & 2 \\
\hline Students learned about the religious diversity of Africa & 2 \\
\hline
\end{tabular}




\section{Learning about the Journey of Africans to America}

Students learned about the history of slavery from the program. They reported learning a good deal about the institution of slavery in America, the treatment of African Americans in slavery, and the social history of African Americans during slavery. They also reported learning about African American culture during this time period, as well as about different perspectives on race that existed in previous times. The topic of food and culture also captivated students, particularly as it related to social history (why people eat what they eat). They also reported learning about the existence of free African Americans during this time, and about the complexities of slavery, such as the existence of slavery in Africa before the arrival of whites, and the participation of Africans in the slave trade.

\begin{tabular}{|l|c|}
\hline $\begin{array}{l}\text { Students learned about the treatment of slaves and } \\
\text { everyday circumstances of life as a slave }\end{array}$ & 36 \\
\hline $\begin{array}{l}\text { Students learned about culture and food ways of African } \\
\text { Americans }\end{array}$ & 7 \\
\hline $\begin{array}{l}\text { Students learned about the complexities of race, color, } \\
\text { and ancestry }\end{array}$ & 5 \\
\hline Students learned about slave resistance & 4 \\
\hline $\begin{array}{l}\text { Students learned a complex story of the slave trade and } \\
\text { slavery }\end{array}$ & 3 \\
\hline $\begin{array}{l}\text { Students learned about the Free African American } \\
\text { Community }\end{array}$ & 1 \\
\hline
\end{tabular}

\section{Learning About the Lives African Americans Made for Themselves}

Through the program, students also learned about the opportunities available to African Americans during and after slavery. Many students pointed to learning about African American leaders as a key part of the program. Others were interested to learn about the variety of economic opportunities that African Americans took advantage of (e.g. black-owned businesses, work at Ford's, etc.). Through the trip to the African American festival in Ann Arbor, some students connected the current artwork done by African Americans to the African American history they had learned in the program. 


\begin{tabular}{|l|c|}
\hline $\begin{array}{l}\text { Students learned about key figures in African American } \\
\text { history and leadership }\end{array}$ & 9 \\
\hline $\begin{array}{l}\text { Students learned about the diversity of opportunities } \\
\text { available for African Americans in the twentieth century }\end{array}$ & 5 \\
\hline $\begin{array}{l}\text { Students learned about the rich culture of African } \\
\text { Americans }\end{array}$ & 5 \\
\hline $\begin{array}{l}\text { Students were able to connect African American culture } \\
\text { and art to the history that they learned about }\end{array}$ & 3 \\
\hline $\begin{array}{l}\text { Students learned about the variety of black owned } \\
\text { businesses and enterprises }\end{array}$ & 1 \\
\hline
\end{tabular}

\section{Conclusion}

While students in high school had been taught something about African American history in school (at least according to state curriculum guidelines), it was clear that the museum and other experiences presented new information to them. Part of this might be due to the structure of the Michigan curriculum, in which learning about early American history (including the slave trade) is taught in elementary school, slavery and the Civil War in eighth grade, and modern U.S. and World history in high school. The organization of the curriculum places foundational knowledge of African American history at a grade level where the information is not often taught with depth and complexity. Students might be exposed to African American history in community or church settings, but this exposure outside the classroom could not be guaranteed.

The students' school and Bright Futures followed-up on the field trip experience the next year. Bright Futures purchased books for an African American history and culture library for their program room. The program bought many of these books from Black Stone Bookstore and Cultural Center, our local African American bookstore. A local historian, Matt Siegfried, gave talks and a walking tour to students the next year. A grant for teachers, partially funded by Bright Futures, brought art to the streets of Ypsilanti as Lynne Settles, the art teacher at Ypsilanti Community High School, had her class create an African American history mural on the life of A.J. Jacobs on Ypsilanti's Harriet Street this fall. She plans future student-created murals in the community.

Out-of-school programs, such as Bright Futures, can provide students a chance to get outside their school and neighborhood to explore both their own culture and the cultures of other groups. Given the financial limitations and other constraints of schools, these opportunities can provide students with some of their only experiential options for programming. Out-of-school-time programs provide a unique resource for helping students broaden their perspective on history and culture. 